Dzieje Najnowsze, Rocznik L - 2018, 3

PL ISSN 0419-8824

Paweł Duber

Bristol

\title{
Kulisy ustąpienia Aleksandra Prystora ze stanowiska premiera w maju 1933 r.
}

\begin{abstract}
Abstrakt: Ustąpienie Aleksandra Prystora z funkcji premiera w 1933 r. miało związek z utratą przez niego zaufania Piłsudskiego. Historycy wiązali ten fakt ze starzeniem się Marszałka. Analiza dostępnego materiału źródłowego pozwala jednak rzucić nowe światło na kulisy tej dymisji. Okazuje się, że podjął szereg istotnych decyzji, łącząc poszczególne resorty oraz powołując nowych ministrów, nie konsultując jednak tego wcześniej z Piłsudskim. Doprowadziło to ostatecznie do konfliktu pomiędzy obu politykami.
\end{abstract}

Słowa kluczowe: rządy sanacyjne, autorytaryzm, pułkownicy, polityka wewnętrzna, ostatnie lata życia Józefa Piłsudskiego, konflikty w kierownictwie obozu sanacyjnego.

Abstract: Aleksander Prystor's resignation from the post of prime minister in 1933 was related to the fact that he lost Marshal Piłsudski's trust. Historians associated this with the Marshal's old age. An analysis of available source material, however, sheds new light on the inside story of this resignation. It turns out that Prystor made a number of important decisions, combining various ministries together and appointing new ministers, without consultation with Piłsudski. This led to a conflict between the two politicians.

Key w ords: Sanacja regime, authoritarianism, colonels' regime, internal policy, Piłsudski's last years, conflicts within the Sanacja Camp.

Ostatnie lata życia Marszałka nie były wolne od tarć i konfliktów w kierownictwie obozu sanacyjnego. Za najbardziej jaskrawe z nich odpowiadał on sam, o czym można się przekonać, analizując okoliczności odwołania premiera Aleksandra Prystora. Józef Piłsudski zmusił go do złożenia dymisji w maju 1933 r., budząc tym samym zdziwienie i rozgoryczenie w gronie swoich bliskich współpracowników. Było to o tyle niezwykłe, że chodziło przecież o jego 
wieloletniego przyjaciela jeszcze z czasów Organizacji Bojowej PPS, uważanego dotychczas za „najwierniejszego z wiernych”. Sprawie tej poświęcono już co prawda sporo uwagi w licznych opracowaniach, ich autorzy nie wykroczyli jednak w swoich analizach poza sfere przypuszczeń, niekiedy naznaczonych uprzedzeniami w stosunku do Piłsudskiego ${ }^{1}$. Oczywiście po upływie wielu lat wyjaśnienie wszystkich okoliczności tamtych wydarzeń jest już niemożliwe, analiza dostępnego materiału źródłowego pokazuje jednak, że postępowanie Piłsudskiego było bardziej racjonalne, niż może się to z pozoru wydawać.

Jeden z pierwszych poważniejszych sygnałów zwiastujących „nadciagająca burzę" stanowiła rozmowa Kazimierza Świtalskiego z Piłsudskim, do której doszło 24 I 1933 r. Marszałek oświadczył swojemu rozmówcy, że rząd popełnił błąd podczas ustalania wysokości budżetu wojskowego, który jego zdaniem jest o 60 mln zł za duży. Fakt ten uznał za „świństwo”, ponieważ „rozpoczą grę w sprawie rozbrojenia i powiększenie budżetu może się stać atutem [...] w cudzych rękach". Stwierdzenie to miało oczywiście zwiąek z działaniami prowadzonymi wówczas przez Piłsudskiego na arenie międzynarodowej ${ }^{2}$, powyższe zarzuty stanowiły jednak dla Świtalskiego duże zaskoczenie. Próbując wytłumaczyć je w swoich zapiskach, słusznie dopatrzył się w nich jakiegoś ukrytego znaczenia, którego nie był jednak w stanie odgadnaćc. Sprawy nie ułatwiał mu także sam Piłsudski, nie chcąc udzielić dalszych informacji na ten temat. Świtalski słusznie doszedł więc do wniosku, że tak naprawdę nie chodziło o fakt dokonania takich lub innych zmian $\mathrm{w}$ sumie wydatków przeznaczonych na cele wojskowe, lecz była to, używając jego określenia, „formalność” polegająca na odgrodzeniu się „od budżetu wojskowego, za który [Piłsudski] nie chce brać odpowiedzialności”’. Cała ta sprawa

\footnotetext{
${ }^{1}$ Zob. m.in.: A. Ajnenkiel, Polska po przewrocie majowym. Zarys dziejów politycznych Polski 1926-1939, Warszawa 1980, s. 307-309; A. Chojnowski, Pitsudczycy u władzy. Dzieje Bezpartyjnego Bloku Wspótpracy z Rzqdem, Wrocław 1986, s. 201-203; J. Halbersztadt, Aleksander Prystor, premier Rzeczypospolitej 27 V 1931 - 9 V 1933, w: Prezydenci i premierzy Drugiej Rzeczypospolitej, red. A. Chojnowski, P. Wróbel, Wrocław 1992, s. 322-323; J. Piotrowski, Aleksander Prystor 1874-1941. Zarys biografii politycznej, Wrocław 1994, s. 116-118; A. Garlicki, Józef Pitsudski 1867-1935, Warszawa 1989, s. 669-673; T. Nałęcz, Niemoc herosa. Ostatnie lata Józefa Piłsudskiego, w: Od Piłsudskiego do Wałęsy. Studia $z$ dziejów Polski w XX wieku, red. K. Persak i in., Warszawa 2008, s. 42-44.

${ }^{2}$ Wystarczy wspomnieć, że w Genewie toczyły się wówczas ważne rozmowy na temat rozbrojenia, w trakcie których 6 lutego Edward Raczyński przedstawił polską koncepcję tego zagadnienia, czasami nazywana polskim planem minimalnym. Zob. J. Beck, Wspomnienia o polskiej polityce zagranicznej 1926-1939, oprac. A.M. Cienciała, Warszawa-Kraków 2015, s. 92-93; Historia dyplomacji polskiej, t. IV: 1918-1939, red. P. Łossowski, Warszawa 1995, s. 450-451.

${ }^{3}$ K. Świtalski, Diariusz 1919-1935, do dr. przygot. A. Garlicki, R. Świętek, Warszawa 1992, s. 642. Na temat przypuszczalnych przyczyn podobnego zachowania z jego strony zob. J. Halbersztadt, Józef Pitsudski a mechanizm podejmowania decyzji wojskowych w latach 1926-1935, „Przegląd Historyczny” 1983, t. LXXIV, nr 4, s. 714.
} 
świadczyła o coraz bardziej krytycznym nastawieniu Marszałka do gabinetu Prystora, o którym stwierdził, że jest na niego „obrażony”4.

O narastaniu poważnego konfliktu pomiędzy Marszałkiem a jego wieloletnim przyjacielem świadczył sposób, w jaki trzy miesiące później została przeprowadzona nominacja Emila Kalińskiego na urząd ministra poczt i telegrafów. Piłsudski nie zawiadomił szefa rządu o swoich planach, przekazując mu podjęta przez siebie decyzję za pośrednictwem jednego $\mathrm{z}$ oficerów Generalnego Inspektoratu Sił Zbrojnych (GISZ), stawiając tym samym Prystora przed faktem dokonanym ${ }^{5}$. Osoba, która poinformowała premiera o planowanej zmianie, był Adam Ludwik Korwin-Sokołowski. Zgodnie z jego relacją do rozmowy na ten temat doszło 13 kwietnia, a więc zaledwie dzień przed planowanym rozpoczęciem urzędowania przez nowego ministra. Prystor, zaskoczony i poirytowany, nie chciał się oczywiście zgodzić na narzucenie mu następcy zmarłego Ignacego Bernera. Zaczał w związku z tym wysuwać „szereg zastrzeżeń natury [...] formalno-prawnej”. Sokołowski posiadał jednak $\mathrm{w}$ tej sprawie precyzyjne instrukcje, stwierdził więc stanowczo, że Marszałek od swoich żądań nie odstapi. Co więcej, pokonanie wszelkich przeszkód z tym związanych pozostawił premierowi. Prystor widząc bezcelowość swojego sprzeciwu, obiecał wprowadzić Kalińskiego na urząd ministra poczt i telegrafów następnego dnia ${ }^{6}$. Po wysłuchaniu sprawozdania z tej rozmowy Piłsudski raz jeszcze polecił swojemu wysłannikowi udać się do premiera w celu zakomunikowania mu, że wycofa się z rządu w przypadku braku formalnego uregulowania planowanej nominacji w ciagu najbliższych dwóch dni ${ }^{7}$. Groźba ta była równoznaczna z wyrażeniem braku zaufania do urzędującego szefa rządu, po 1926 r. Piłsudski sprawował bowiem funkcję ministra spraw wojskowych we wszystkich gabinetach, jego ustapienie musiało więc pociagnąc za soba dymisję premiera i pozostałych ministrów. Chcąc upewnić się, że powyższe żądania zostana załatwione po jego myśli, Piłsudski polecił Sokołowskiemu spotkać się z prezydentem Mościckim, o czym Prystor został poinformowany w trzeciej już tego dnia rozmowie. Autor cytowanej relacji wyciagną na tej podstawie słuszny wniosek, że Piłsudski poprzez podobne zachowanie dążył do obalenia rządu, jednak w związku z błyskawicznym załatwieniem nominacji Kalińskiego zrezygnował ze swojego zamiaru'. Trudno się więc dziwić, że premier wręczając marszałkowi sejmu Świtalskiemu dekret zwołujący

\footnotetext{
${ }^{4}$ K. Świtalski, Diariusz..., s. 642.

${ }^{5}$ Ibidem, s. 644-645.

${ }^{6}$ A.L. Korwin-Sokołowski, Fragmenty wspomnień 1910-1945, Paryż 1985, s. 102.

7 Ibidem.

${ }^{8}$ Ibidem, s. 102-103. Spotkanie Piłsudskiego z Kalińskim, a także wizytę Sokołowskiego u Mościckiego odnotowali również adiutanci Marszałka. Zob. Biblioteka Narodowa (dalej: BN), akc. 10120, Dziennik Adiutantury Belwederu, k. 45-46. Problem ten został poruszony przez Prystora w rozmowie z Bronisławem Żongołłowiczem, który zapisał jej treść w swoich Dziennikach. Zob. B. Żongołłowicz, Dzienniki 1930-1936, oprac. D. Zamojska, Warszawa 2004, s. 486-487.
} 
Zgromadzenie Narodowe na 8 maja w celu dokonania wyboru nowego prezydenta, nie krył swojego rozgoryczenia, ponieważ w jego ocenie Piłsudski nie szukał z nim „,żadnego kontaktu”, a bieżące sprawy załatwiał „przez swoich oficerów”. Przyznał tym samym wprost, że jego stosunki z Piłsudskim uległy znacznemu ochłodzeniu.

2 maja Marszałek zorganizował w Belwederze konferencję ze swoimi najbliższymi współpracownikami. Wzięli w niej jednak udział jedynie Świtalski i Walery Sławek, zabrakło natomiast Prystora, ponieważ to właśnie jego osobie poświęcone było spotkanie. Piłsudski po omówieniu kilku szczegółów związanych ze zbliżającą się elekcja głowy państwa oświadczył, że ma premierowi za złe jego system pracy, polegający „na chęci wiedzenia o wszystkim i wtrącania się do wszystkiego. System taki jest pierwszorzędny i daje się utrzymać tylko przy bardzo usilnej pracy. Gdy następuje zmęczenie, wszystkie złe strony takiego systemu występuja jaskrawo i kończy się to brakiem kontroli. System pracy Prystora podobny jest do systemu Bartla, ale Bartel miał pracę w wyższym stylu”. Jednak najważniejszy zarzut dotyczył rzekomego posługiwania się przez Prystora, jak to określił Marszałek, „"swoimi» ludźmi, których traktuje jako swoich zaufanych i których opłaca (pieniędzmi czy stanowiskami). Te małe pieski [...] w każdej chwili moga Prystora skompromitować pod względem moralnym. Tworzą się jakieś komploty [...], które grożą, że [...] może [...] przyjść do skandalu, który Prystora skompromituje i uniemożliwi użycie go później” ${ }^{10}$. Trudno jednoznacznie zinterpretować powyższe zarzuty. Niewykluczone, że związane one były z pogłoskami docierajaccymi zapewne do Piłsudskiego na temat nie najlepszej kondycji obozu rządzącego i trawiących go konfliktów wewnętrznych, o udział w których podejrzewał urzędującego szefa rządu. Stwierdził więc, że w związku ze zbliżającymi się wyborami nowego prezydenta prezes Rady Ministrów powinien podać się do dymisji. Ostrzegł także, iż w przeciwnym razie zachowa wobec niego „nieżyczliwa neutralność”, choć zastrzegł, że zna go zbyt długo, aby „sobie wobec niego pozwolił na jakieś niemiłe kroki, w rodzaju niepodania ręki”. Świtalski na podstawie powyższych słów słusznie wywnioskował, że „Komendant ma jakaśs urazę i pretensję do Prystora, której nie obiecuje prędko zapomnieć"11.

Piłsudski, pomimo licznych argumentów wysuwanych przez swoich rozmówców w obronie premiera, nie zmienił negatywnej opinii na jego temat. Autor cytowanej relacji starając się dociec przyczyn tego stanu rzeczy, stwierdził w swoich zapiskach, że Marszałek, prowadząc samotny tryb życia, skazywał się na opinie wyrażane przez przypadkowe osoby ${ }^{12}$. To ewidentna aluzja do

\footnotetext{
${ }^{9}$ K. Świtalski, Diariusz..., s. 646-647.

10 Ibidem, s. 647-648.

11 Ibidem, s. 648.

${ }^{12}$ Ibidem, s. 648-649.
} 
pogłębiającej się alienacji Piłsudskiego, która mogła mieć oczywiście pewien wpływ na jego ówczesne postępowanie. Warto zreszta pamiętać, że nie była to wówczas jedyna tego typu sprawa, ponieważ doszło również do nieoczekiwanego odwołania Bogusława Miedzińskiego z funkcji przewodniczącego Komisji Wojskowej, co mogło mieć pewien związek ze zmianą na stanowisku premiera ${ }^{13}$. Konflikty te znane oczywiście były zaledwie garstce wtajemniczonych osób tworzących ścisłe kierownictwo obozu sanacyjnego, o co dbał zreszta sam Marszałek. Świadczy o tym jeden z fragmentów wspomnień abp. Józefa Gawliny. Opisał on przebieg swojego spotkania z Piłsudskim, do którego doszło w kwietniu 1933 r. po defiladzie wojskowej zorganizowanej z okazji oswobodzenia Wilna. Zdaniem autora w zachowaniu bioracych w niej udział dygnitarzy dawało się wyczuć napięcie, podczas gdy „Prystor używał tonu zupełnie swobodnego"14. Relacja ta pokazuje wyraźnie, iż obaj panowie starannie unikali manifestowania na zewnątrz dzielących ich różnic. Ukazuje także dystans panujący pomiędzy Piłsudskim a jego otoczeniem, choć nie należy zapominać, że były to subiektywne odczucia Gawliny i niekoniecznie odzwierciedlały one w pełni ówczesne realia.

Przebieg przytoczonej wcześniej rozmowy z 2 V 1933 r. nie mógł stanowić zbyt dużego zaskoczenia dla Świtalskiego i Sławka, natomiast Prystor, gdy dowiedział się od nich o jej przebiegu, poczuł się szczególnie dotknięty porównaniem go do Bartla. Premier nie mając oczywiście zamiaru sprzeciwiać się woli Piłsudskiego, ze złożeniem swojej dymisji czekał już tylko na wybór nowej głowy państwa. Współpracownicy Marszałka próbowali natomiast dociec, kto był odpowiedzialny za zaistniały stan rzeczy, dochodząc do wniosku, że Piłsudski musiał czerpać swoje informacje od osób postronnych. Padło wówczas m.in. nazwisko Aleksandry Zagórskiej, bliskiej przyjaciółki rodziny Piłsudskich ${ }^{15}$. Byli jednak bezradni, co budziło oczywiście ich poważne zaniepokojenie, istniało bowiem niebezpieczeństwo, że podobna sytuacja może się w przyszłości powtórzyć. Świtalski stwierdził co prawda, powołując się na treść swojej rozmowy z Beckiem, że w polityce zagranicznej osąd Piłsudskiego

${ }^{13}$ Szerzej na ten temat zob. D. Malczewska-Pawelec, Bogustaw Miedziński (1891-1972). Polityk i publicysta, Łódź 2002, s. 151, 166-167; A. Adamczyk, Bogusław Miedziński (1891-1972). Biografia polityczna, Torun 2000, s. 184.

14 J. Gawlina, Wspomnienia, oprac. J. Myszor, Katowice 2004, s. 87-88. Z istnienia poważnego konfliktu pomiędzy premierem a Generalnym Inspektorem Sił Zbrojnych nie zdawał sobie sprawy m.in. Adam Krzyżanowski, dobrze przecież zorientowany w stosunkach panujących wśród sanacyjnej „góry”, który nawet z perspektywy wielu lat wiązał dymisję premiera ze zbliżającymi się wyborami prezydenckimi. Co więcej, jego zdaniem najpoważniejszym kandydatem Piłsudskiego na to stanowisko miał być początkowo właśnie Prystor. Zob. A. Krzyżanowski, Dzieje Polski, Paryż 1973, s. 192.

${ }^{15} \mathrm{O}$ tym, jak bliskie relacje o charakterze osobistym łączyły tę znaną działaczkę niepodległościową z Piłsudskim, którego znała jeszcze z czasów Organizacji Bojowej PPS, świadczy treść jej wspomnień, przechowywanych w formie maszynopisu w zbiorach Biblioteki Narodowej. Zob. BN, akc. 8579, A. Zagórska, Spotkania moje z Józefem Piłsudskim, B. 1-39. 
nadal pozostaje trzeźwy ${ }^{16}$, słowa te należy jednak uznać za otwarta krytykę jego postępowania w zakresie polityki wewnętrznej. Prystorowi nie pozostało zatem nic innego, jak złożyć dymisję gabinetu tuż po ponownym wyborze Mościckiego na urząd Prezydenta RP ${ }^{17}$.

Trudno z całkowita pewnościa stwierdzić, jakie powody skłoniły Marszałka do podjęcia podobnych kroków względem swojego bliskiego przyjaciela i współpracownika. Być może rację miał Świtalski, który tłumaczył ten fakt izolacją Piłsudskiego, o czym mógł świadczyć fakt, że w 1931 r. wszystkie najważniejsze decyzje omawiał $\mathrm{w}$ gronie swoich najbliższych współpracowników, podczas gdy obecnie Prystor, Świtalski oraz Sławek dowiadywali się często o jego posunięciach za pośrednictwem osób trzecich. Dobrym przykładem podobnej sytuacji jest właśnie sprawa wyboru prezydenta w 1933 r., gdy ścisłe kierownictwo obozu sanacyjnego do ostatniego momentu nie miało całkowitej pewności, czy Marszałek po raz kolejny powierzy ten urząd Ignacemu Mościckiemu, czy też zdecyduje się wskazać innego kandydata ${ }^{18}$. Nie nadarzyło się również zbyt wiele okazji do omawiania z nim bieżących spraw, co potwierdzaja zapiski jego adiutantów. Wynika z nich jednoznacznie, że pomiędzy 22 X 1932 a 3 XII 1933 r. Marszałek ograniczał swoje kontakty głównie do urzędującego premiera. Stałym gościem w Belwederze, budynku GISZ, a nawet w Wilnie był natomiast płk Józef Beck, co miało naturalnie związek z faktem, iż poza wojskiem Piłsudski interesował się wówczas głównie polityką zagraniczną ${ }^{19}$. Co ciekawe, to właśnie Zagórska przytoczyła w swoich wspomnieniach fragment rozmowy ze Sławkiem, który przyznał, że czasem musi „czekać kilka miesięcy na zobaczenie się z Komendantem”"20. Piłsudski żywił najwyraźniej coraz większą niechęć do swoich wieloletnich współpracowników, o czym zdaje się świadczyć jeden z fragmentów zapisków gen. Kordiana Zamorskiego, ówczesnego zastępcy szefa Sztabu Głównego, który pod datą 3 III 1932 r. odnotował wypowiedź płk. Tadeusza Jakubowskiego: „Pani Marszałkowa podobno bardzo boleje nad tym, że Kmdt odsunął wszystkich starych ludzi od siebie" ${ }^{21}$. Jest to co prawda relacja pochodząca już nawet nie

${ }^{16}$ K. Świtalski, Diariusz..., s. 649-650

17 Zdaniem Romana Wapińskiego postawa premiera wynikała nie tylko z lojalności wobec Piłsudskiego, lecz także z faktu, iż „w odróżnieniu od takich dawnych uczestników kręgu towarzyskiego Piłsudskiego, jak Stanisław Wojciechowski czy Leon Wasilewski, swą pozycję w życiu politycznym, tak jak pozostali tworzący ten krag po maju 1926 r., zawdzięczał wyłącznie temu, że był wiernie spełniającym jego polecenia podkomendnym. Wyrażona więc przez Piłsudskiego dezaprobata [...] była równoznaczna z utratą zajmowanej pozycji”. Zob. R. Wapiński, Polityka i politycy. O polskiej scenie politycznej XX wieku, Wrocław 2006, s. 214-215.

${ }^{18}$ K. Świtalski, Diariusz..., s. 544-546; B. Żongołłowicz, op. cit., s. 492.

${ }_{19}$ BN, akc. 10120, Dziennik Adiutantury..., passim. Zob. też: A. Hrynkiewicz, Dziennik adiutanta Marszatka Józefa Pitsudskiego, „Zeszyty Historyczne” 1988, nr 85, s. 75-138.

${ }^{20}$ BN, akc. 8579, A. Zagórska, Spotkania..., k. 24.

${ }^{21}$ „Zapiski” generała Józefa Kordiana Zamorskiego, oprac. W. Mroczkowski, T. Sierocki, „Najnowsze Dzieje Polski. Materiały i studia z okresu 1914-1939” 1963, t. VI, s. 202. 
$\mathrm{z}$ drugiej, lecz z trzeciej ręki, znajduje ona jednak potwierdzenie $\mathrm{w}$ innych cytowanych źródłach. Nie ma więc racji Przemysław Olstowski, który uważa, że „do najczęściej odwiedzajacych Komendanta w ostatnich latach jego życia należeli w pierwszym rzędzie Sławek, Świtalski i Beck”"22. Zdanie to można bowiem odnieść jedynie do ostatniego z wymienionych polityków.

Stopniowe odsuwanie się Piłsudskiego od grona dawnych współpracowników siłą rzeczy musiało mieć istotny wpływ na stosunek do Prystora, fakt ten nie stanowi jednak wystarczającego wytłumaczenia jego niezrozumiałego zachowania z pierwszych miesięcy $1933 \mathrm{r}$. Zdaniem niektórych historyków pewna rolę $\mathrm{w}$ tej sprawie odegrała również wzajemna niechęć pomiędzy żonami obu polityków ${ }^{23}$, o czym zdaje się świadczyć szereg dostępnych relacji źródłowych, które warto w tym miejscu przytoczyć. Aleksandra Piłsudska, pomimo wcześniejszego zaproszenia, nie pojawiła się ostentacyjnie na „herbatce” wydanej przez premiera i jego żonę w Wilnie w ramach obchodów upamiętniających wyzwolenie miasta, udając się na spotkanie rodziny wojskowej $\mathrm{w}$ kasynie garnizonowym ${ }^{24}$. O wzajemnej niechęci pomiędzy obu paniami wspominali także Jadwiga Dunin-Wasowiczowa oraz Henryk Gruber ${ }^{25}$. Co więcej, Piłsudski formułując swoja negatywna opinię na temat Prystora, niezbyt pochlebnie wyrażał się także o jego żonie ${ }^{26}$. Piłsudska w swoich spisywanych po latach wspomnieniach pominęła jednak ten fakt milczeniem, stwierdzając jedynie, że jej mąż od samego początku nie uważał Prystora za dobrego kandydata na stanowisko premiera ${ }^{27}$.

Napięcie pomiędzy obiema kobietami, dostrzegalne nawet przez postronnych obserwatorów, wiąże się także z innym ciekawym wątkiem, który mógł odegrać pewną rolę w opisywanych wydarzeniach. Podczas jednej ze swoich rozmów z Bronisławem Żongołłowiczem, podsekretarzem stanu w Ministerstwie Wyznań Religijnych i Oświecenia Publicznego, Prystorowa przyznała,

${ }_{22}^{2}$ P. Olstowski, Generat Gustaw Orlicz-Dreszer (1889-1936). Dowódca wojskowy i działacz społeczno-polityczny, Toruń 2000, s. 293.

${ }^{23}$ Zwolennikami tej tezy są m.in. Jacek Piotrowski, Jerzy Halbersztadt oraz Piotr Mydlach. Zob. J. Piotrowski, op. cit., s. 115; J. Halbersztadt, Aleksander Prystor..., s. 322-323; P. Mydlach, Gabinet Aleksandra Prystora (27 V 1931 - 9 V 1933), w: Studia z historii społeczno-gospodarczej XIX $i$ XX wieku, t. I, red. W. Puś, Łódź 2003, s. 275-276.

${ }_{24}$ BN, akc. 10120, Dziennik Adiutantury..., k. 51-52; B. Żongołłowicz, op. cit., s. 488.

25 J. Dunin-Wąsowiczowa, Wspomnienia, Warszawa 2005, s. 48-49; H. Gruber, Wspomnienia $i$ uwagi 1892-1942, Londyn 1968, s. 256.

${ }^{26}$ K. Świtalski, Diariusz..., s. 649.

27 A. Piłsudska, Wspomnienia, oprac. A. Adamczyk, Warszawa 2004, s. 294. Opinia ta nie znajduje żadnego pokrycia w dostępnym materiale źródłowym i nie może być poważnie brana pod uwagę. Co więcej, w osobnej relacji poświęconej Prystorowi, opublikowanej jeszcze w latach II wojny światowej, autorka przeinaczyła podstawowe fakty, pisząc o nim w następujacy sposób: „W roku 1932 zostaje premierem. Wraz ze swym przyjacielem Walerym Sławkiem organizuje BBWR. Inicjatywę dał im Piłsudski, który myślał o konieczności złagodzenia różnic klasowych [...]”. Zob. eadem, Wspomnienie o Prystorze, „Niepodległość” (Nowy Jork-Warszawa) 1997, t. XLIX, s. 113. 
że stosunek Piłsudskiego zarówno do jej męża, jak i do niej uległ zmianie z powodu Eugenii Lewickiej, ponieważ oboje „stali przy Piłsudskiej i przy dziewczynkach przeciwko Marszałkowi”" ${ }^{28}$. Trudno jednoznacznie zinterpretować podobne stwierdzenie i wyciagnać na jego podstawie jakieś konkretne wnioski. Pozornie stanowi ono dodatkowe wytłumaczenie niechęci Piłsudskiego do Prystora w tamtym okresie, jednak nie wyjaśnia negatywnego stosunku Aleksandry do Janiny Prystor, która miała ją przecież wspierać w trudnych dla niej chwilach. Wiąże się to zresztą z rolą, jaką odegrała Lewicka w biografii Piłsudskiego na przełomie lat dwudziestych i trzydziestych, szczególnie w kontekście jej domniemanego romansu z Marszałkiem oraz zagadkowej śmierci ${ }^{29}$. Sprawa ta już chyba na zawsze pozostanie tajemnica. Tym bardziej nie sposób jednoznacznie ocenić jej wpływu na stosunki Piłsudskiego z małżeństwem Prystorów.

W oparciu o dostępny materiał źródłowy można jednak pokusić się o próbę wskazania bardziej wiarygodnych przyczyn, które miały zapewne decydujacy wpływ na takie, a nie inne zachowanie Marszałka. W tym celu należy odwołać się jednak do wydarzeń nieco wcześniejszych, o których można się dowiedzieć z prowadzonych na bieżąco zapisków wspomnianego Żongołłowicza. Pomimo dosyć „plotkarskiego” charakteru stanowią one cenne źródło, ponieważ ich autor przyjaźnił się blisko nie tylko z szefem rządu, lecz także z jego małżonka, tym samym docierały do niego informacje pochodzace z pierwszej ręki. Okazuje się, że 16 III 1932 r., gdy Piłsudski przebywał poza krajem ${ }^{30}$, Prystorowa wyraziła obawę, iż planowane przez jej męża zmiany w rządzie, polegające m.in. na połączeniu Ministerstwa Reform Rolnych z Ministerstwem Rolnictwa oraz powołaniu w skład gabinetu Władysława Zawadzkiego, doprowadzą do konfliktu z Piłsudskim. Stwierdziła również: „Marszałek zmęczony, kapryśny, może to zdezawuować, gdy wróci... Wówczas Olek będzie skończony, jak Matuszewski i wielu innych..." ${ }^{31} 25$ marca ponownie poruszyła ten temat w rozmowie z Żongołłowiczem, tym razem dodając również, że przeprowadzone przez jej męża zmiany doprowadzą do jego upadku, ponieważ przeciwko niemu „skupiaja się Br. Pieracki, Świtalski, Miedziński, Kozłowski, Matuszewski, syn Prezydenta Mościcki. Żony ich kupią się wokół Marszałkowej Piłsudskiej,

${ }_{28}$ B. Żongołłowicz, op. cit., s. 337-338. O silnych podziałach w otoczeniu Marszałka, związanych z tą sprawa, wspominała także Dunin-Wassowiczowa, należąca w tym okresie do bliskiego kręgu znajomych Aleksandry Piłsudskiej. Zob. J. Dunin-Wąsowiczowa, op. cit., s. 19-23.

${ }^{29}$ O sprawie tej można więcej przeczytać w dostępnych biografiach Piłsudskiego. Szerzej zob. A. Garlicki, op. cit., s. 606-607; W. Suleja, Józef Pitsudski, Wrocław 1995, s. 345.

${ }^{30}$ Przebywał wówczas w Egipcie. Zob. W. Jędrzejewicz, J. Cisek, Kalendarium życia Józefa Pitsudskiego 1867-1935, t. IV: 1927-1935, Kraków-Łomianki 2007, s. 258.

31 B. Żongołłowicz, op. cit., s. 309. Faktycznie jeszcze w 1931 r. stojacy wówczas na czele Ministerstwa Skarbu Ignacy Matuszewski został przez Piłsudskiego zmuszony do rezygnacji w okolicznościach, które jak żywo przypominały wydarzenia towarzyszące ustapieniu Prystora. Zob. P. Duber, Konflikty w kierownictwie obozu sanacyjnego po powrocie Józefa Pitsudskiego z Madery w 1931 r., „Kwartalnik Historyczny” 2012, nr 1, s. 69-75. 
usiłując ją nastawić przeciw Premierowej...”32 31 marca Żongołłowicz raz jeszcze zanotował wypowiedź zaniepokojonej Prystorowej, która pomimo uspokajających słów Jana Piłsudskiego w dalszym ciagu obawiała się intryg ze strony innych prominentnych piłsudczyków. Na szkodę jej męża mieli działać m.in. Leon Kozłowski, Michał Mościcki, Miedziński, Ignacy Matuszewski, a przede wszystkim Pieracki, którego Prystor planował podobno przenieść do Ministerstwa Rolnictwa ${ }^{33}$. Okazuje się, że przeciwni planowanym reorganizacjom byli także Sławek, Beck i Świtalski, którzy odradzali premierowi podobne posunięcie „bez współudziału Komendanta i przed jego przyjazdem, tym bardziej, że Komendant [...] raczej [...] radził, by z tymi rzeczami wstrzymał się aż do nowego roku budżetowego". Prystor nie chciał jednak ustapić, argumentujacc, że rekonstrukcja gabinetu była podyktowana stale pogarszajacca się sytuacją gospodarczą oraz koniecznością szukania ciagłych oszczędności m.in. poprzez łączenie ze sobą niektórych resortów, np. Ministerstwa Komunikacji z Ministerstwem Robót Publicznych ${ }^{34}$. Co więcej, na czele połączonego Ministerstwa Rolnictwa i Ministerstwa Reform Rolnych premier faktycznie planował postawić Pierackiego, który nominacji tej jednak nie przyjął. Pomiędzy oboma politykami miało przy tej okazji dojść do dosyć ostrej wymiany zdań, która - jak to określił Świtalski - „pozostawiła między tymi [...] ludźmi duże rozdrażnienia i nieufność” ${ }^{35}$. Fakt ten trudno jednak uznać za wystarczające potwierdzenie cytowanych wcześniej oskarżeń Prystorowej, wysuwanych pod adresem ówczesnego ministra spraw wewnętrznych, świadczy natomiast o silnym oporze i watpliwościach, jakie reformatorskie „zapędy” Prystora budziły wśród innych członków sanacyjnego kierownictwa.

Ciekawe, że po powrocie Marszałka do kraju premier żadnego „besztania” nie dostał, a Piłsudski ,ani jednym włosem wassów nie poruszył”, wysłuchując relacji Prystora na temat planowanych zmian. Co więcej, miał być o nich rzekomo poinformowany przed swoim wyjazdem do Egiptu ${ }^{36}$. W świetle przytoczonych wcześniej relacji fakt ten należy jednak uznać za wątpliwy, a premier, pomimo braku poparcia ze strony Piłsudskiego, postanowił najwyraźniej postawić na swoim, doprowadzając ostatecznie do zapowiadanego przez siebie połaczenia Ministerstwa Rolnictwa z Ministerstwem Reform Rolnych oraz powołując do rządu Zawadzkiego w miejsce Jana Piłsudskiego, brata Marszałka ${ }^{37}$.

32 B. Żongołłowicz, op. cit., s. 312.

${ }^{33}$ Ibidem, s. 314. 11 V 1933 r., a więc tuż po ustapieniu Prystora, stwierdziła, nie kryjąc rozgoryczenia, iż przeciwko jej mężowi spiskowali Beck, Bronisław Nakoniecznikow-Klukowski, Zawadzki, Pieracki oraz Jędrzejewicz. Zob. ibidem, s. 497.

${ }^{34}$ K. Świtalski, Diariusz. Uzupetnienie z lat 1919-1932, do dr. przygot. P. Duber, W. Suleja, Warszawa 2012, s. 158.

35 Ibidem, s. 159.

36 B. Żongołłowicz, op. cit., s. 337.

${ }^{37}$ J. Faryś, Gabinet Aleksandra Prystora 27.V.1931 - 9.V.1933, w: Gabinety Drugiej Rzeczypospolitej, red. J. Faryś, J. Pajewski, Szczecin-Poznań 1991, s. 236. 
Piłsudski nie oponował, tak jakby stracił zainteresowanie działaniami podejmowanymi przez Prystora. Jednak zdaniem dobrze poinformowanego Żongołłowicza właśnie od tego momentu jego stosunki z premierem zaczęły się pogarszać. Co więcej, w rozmowach z nim miał się stopniowo ograniczać jedynie do problematyki wojskowej oraz polityki zagranicznej, unikając zagadnień dotyczących polityki wewnętrznej ${ }^{38}$. Wydaje się więc, że Piłsudski nie darował Prystorowi faktu podjęcia wielu istotnych decyzji bez wcześniejszego skonsultowania tego z nim, co z czasem doprowadziło do dymisji szefa rządu. Niewykluczone, że sposób przeprowadzenia nominacji Kalińskiego na ministra poczt i telegrafów był do pewnego stopnia odwetem Piłsudskiego, który poczuł się dotknięty postępowaniem swojego bliskiego przyjaciela. Teoretycznie pewna rolę $\mathrm{w}$ tej sprawie mogła również odegrać walka o władzę w ówczesnym kierownictwie obozu sanacyjnego ${ }^{39}$, o czym zdają się świadczyć cytowane wcześniej opinie Prystorowej. Wydaje się jednak, że należy je uznać za przesadzone, tym bardziej że nie zachowały się praktycznie żadne inne źródła je potwierdzające. Treść notatek Świtalskiego, zaliczanego przecież przez Prystorowa do grupy „spiskowców”, wskazuje zreszta na istnienie daleko posuniętej solidarności w gronie kilku najbliższych współpracowników Piłsudskiego ${ }^{40}$.

Wszystko świadczy więc o tym, że postępowanie Piłsudskiego w 1933 r. można dosyć racjonalne wyjaśnić i nie należy rozpatrywać tego problemu jedynie w kontekście jego humorów bądź też postępującej choroby, jak starają się to czynić niektórzy historycy ${ }^{41}$. Istotną rolę $\mathrm{w}$ tej sprawie odegrała prawdopodobnie polityka wewnętrzna premiera, prowadzona bez akceptacji Piłsudskiego. Co ciekawe, okoliczności odejścia Prystora ze stanowiska szefa rządu nie zachwiały jego ówczesnej pozycji w państwie, w dalszym ciagu należał bowiem do ścisłego kierownictwa obozu sanacyjnego. Rok po opisywanych wydarzeniach udał się nawet z polecenia Marszałka na Litwę w celu sprawdzenia, czy nie istnieją możliwości nawiązania normalnych stosunków dyplomatycznych z tym państwem ${ }^{42}$. Racjonalne podłoże zaistniałego konfliktu nie zmienia natomiast faktu, że Piłsudski żywiąc mniej lub bardziej

${ }^{38}$ B. Żongołłowicz, op. cit., s. 337.

${ }^{39}$ Zwolennikiem podobnej koncepcji jest Arkadiusz Adamczyk. Zob. A. Adamczyk, op. cit., s. 184.

40 Żongołłowicz zamieścił co prawda w swoich Dziennikach informację, uzyskaną od Zawadzkiego, a pochodząca podobno bezpośrednio od Miedzińskiego, zgodnie z którą były minister poczt i telegrafów miał się wrogo odnosić do Bronisława Pierackiego. On sam został natomiast wraz z Kozłowskim zaliczony do przeciwników Prystora. Zob. B. Żongołłowicz, op. cit., s. 351. Wiarygodność tych informacji, noszacych wybitnie charakter pogłosek i pochodzących dodatkowo z drugiej ręki, stoi jednak pod dużym znakiem zapytania, należy je więc uznać za zwykłą ciekawostkę.

${ }^{41}$ Zob. np.: J. Faryśs, op. cit., s. 235; D. i T. Nałęcz, Józef Piłsudski-legendy i fakty, Warszawa 1987, s. 292; T. Nałęcz, op. cit., s. 42-44.

42 J. Piotrowski, op. cit., s. 121-122; Z. Kaczmarek, Marszałkowie Senatu II Rzeczypospolitej, Warszawa 1992, s. 200-202. 
uzasadnione pretensje do swojego wieloletniego przyjaciela, mógł oczywiście rozwiązać zaistniały problem w nieco inny sposób. I właśnie fakt, że tego nie uczynił, należy chyba tłumaczyć jego wiekiem, zmęczeniem oraz ogólnie złym stanem zdrowia. Warto bowiem pamiętać, że pozostały mu wówczas zaledwie dwa lata życia.

\section{Streszczenie}

W maju 1933 r. Aleksander Prystor złożył rezygnację z funkcji premiera tuż po ponownym wyborze Ignacego Mościckiego na prezydenta RP. Szef rządu już od pewnego czasu nie cieszył się zaufaniem Józefa Piłsudskiego, który zachowywał się w stosunku do niego w ostentacyjnie lekceważący sposób, nie szczędząc mu upokorzeń i stawiając go często przed faktem dokonanym $\mathrm{w}$ tak ważnych sprawach, jak obsada stanowisk ministerialnych. Nie ulega watpliwości fakt, iż zachowanie to miało zmusić Prystora do ustapienia. Kontrowersje budza jednak motywy podobnego postępowania, które dla grona najbliższych współpracowników Marszałka stanowiło trudną do rozwiązania zagadkę. Próbowali oni tłumaczyć całą sytuację jego izolacją oraz wpływem, jaki wywierały na niego osoby z bliskiego kręgu rodziny i znajomych. Dziwne zachowanie Marszałka spotkało się także z różnymi ocenami historyków, którzy najczęściej postrzegali je jako przejaw starzenia, wzrastajacej izolacji oraz postępującej choroby. Wpływ na negatywny stosunek Piłsudskiego do Prystora mogły także wywrzeć niechęć, jaką żywiły do siebie żony obu polityków, oraz rzekomy konflikt związany z osobą tragicznie zmarłej Eugenii Lewickiej, która pod koniec lat dwudziestych odegrała niejasną rolę w życiu Marszałka. Analiza dostępnego materiału źródłowego pozwala jednak rzucić nowe światło na kulisy dymisji Prystora. Okazuje się bowiem, że jako szef rządu podjął szereg istotnych decyzji, łącząc poszczególne resorty oraz powołując nowych ministrów, nie konsultując jednak tego wcześniej z Piłsudskim. Doprowadziło to ostatecznie do konfliktu i rezygnacji Prystora z funkcji prezesa Rady Ministrów.

\section{Inside Story of Aleksander Prystor's Resignation from Prime Minister in May 1933}

In May 1933 Aleksander Prystor tendered his resignation from the post of prime minister immediately after Ignacy Mościcki was re-elected as president of the Polish Republic. Already some time ago Prystor had lost Józef Piłsudski's trust, who disparaged him and humiliated ostensibly, often presenting him with a fait accompli in such important matters as appointment of ministerial posts. There is no doubt, however, that such a conduct was intended to force Prystor to resign from his position. Contentious are, however, motives of Piłsudski's behaviour, quite incomprehensible for the Marshal's closest associates. This situation, in their opinion, could have been caused by Piłsudski's isolation, and him being under the influence of his family and friends. This baffling conduct of Piłsudski met with different opinions of historians who most often regarded it as the effect of old age, increasing isolation, and developing illness. Piłsudski's negative attitude toward Prystor could also have been influenced by the feeling of dislike between the wives of both politicians, and an alleged conflict over the person of tragically deceased Eugenia Lewicka who played an unclear role in the Marshal's life at the end of 1920s. An analysis of the available source material, however, sheds new light on the inside story of Prystor's dismissal. It turns out that as head of the government, Prystor made a number of important decisions, combining various departments together and appointing new ministers, without a prior consultation with Piłsudski. This led to a conflict between the two politicians and Prystor's resignation from the position of prime minister. 


\section{Bibliografia}

Adamczyk A., Bogusław Miedziński (1891-1972). Biografia polityczna, Toruń 2000.

Ajnenkiel A., Polska po przewrocie majowym. Zarys dziejów politycznych Polski 1926-1939, Warszawa 1980.

Chojnowski A., Piłsudczycy u władzy. Dzieje Bezpartyjnego Bloku Wspótpracy z Rzqdem, Wrocław 1986.

Duber P., Konflikty $w$ kierownictwie obozu sanacyjnego po powrocie Józefa Piłsudskiego $z$ Madery w 1931 r., „Kwartalnik Historyczny” 2012, nr 1.

Faryś J., Gabinet Aleksandra Prystora 27.V.1931 - 9.V.1933, w: Gabinety Drugiej Rzeczypospolitej, red. J. Faryś, J. Pajewski, Szczecin-Poznań 1991.

Garlicki A., Józef Pitsudski 1867-1935, Warszawa 1989.

Halbersztadt J., Aleksander Prystor, premier Rzeczypospolitej 27 V 1931 - 9 V 1933, w: Prezydenci i premierzy Drugiej Rzeczypospolitej, red. A. Chojnowski, P. Wróbel, Wrocław 1992.

Halbersztadt J., Józef Pitsudski a mechanizm podejmowania decyzji wojskowych w latach 1926-1935, „Przegląd Historyczny” 1983, t. LXXIV, nr 4, s. 677-724.

Historia dyplomacji polskiej, t. IV: 1918-1939, red. P. Łossowski, Warszawa 1995.

Jędrzejewicz W., Cisek J., Kalendarium życia Józefa Piłsudskiego 1867-1935, t. IV: 1927-1935, Kraków-Łomianki 2007.

Kaczmarek Z., Marszatkowie Senatu II Rzeczypospolitej, Warszawa 1992.

Krzyżanowski A., Dzieje Polski, Paryż 1973.

Malczewska-Pawelec D., Bogusław Miedziński (1891-1972). Polityk i publicysta, Łódź 2002. Mydlach P., Gabinet Aleksandra Prystora (27 V 1931 - 9 V 1933), w: Studia z historii spoteczno-gospodarczej XIX i XX wieku, t. I, red. W. Puś, Łódź 2003.

Nałęcz T., Niemoc herosa. Ostatnie lata Józefa Piłsudskiego, w: Od Pitsudskiego do Watęsy. Studia $z$ dziejów Polski $w$ XX wieku, red. K. Persak i in., Warszawa 2008.

Nałęcz D. i T., Józef Piłsudski - legendy i fakty, Warszawa 1987.

Olstowski P., Generat Gustaw Orlicz-Dreszer (1889-1936). Dowódca wojskowy i działacz społeczno-polityczny, Toruń 2000.

Piotrowski J., Aleksander Prystor 1874-1941. Zarys biografii politycznej, Wrocław 1994.

Suleja W., Józef Piłsudski, Wrocław 1995.

Wapiński R., Polityka i politycy. O polskiej scenie politycznej XX wieku, Wrocław 2006.

Biog r a m: Paweł Duber - absolwent Uniwersytetu Śląskiego, dr hab. nauk humanistycznych w zakresie historii. Jego zainteresowania obejmuja następujące obszary badawcze: historia polityczna Polski w XX w., stosunki polsko-francuskie oraz polsko-szwajcarskie, dyplomacja kulturalna, kultura dyplomatyczna, pamięć oraz problem polityki historycznej we współczesnych stosunkach międzynarodowych. Autor wielu książek i artykułów naukowych, m.in. Działalność polityczna Kazimierza Świtalskiego w latach 1926-1939 (2013), Działalność polityczna Kazimierza Bartla w latach 1926-1930. Z dziejów „liberalnego skrzydta” obozu sanacyjnego (2014). E-mail: pduber@o2.pl. 